\title{
Using Knowledge Building to Foster Conceptual Change
}

\author{
Chwee Beng Lee ${ }^{1}$, Ching Sing Chai ${ }^{2}$, Chin-Chung Tsai ${ }^{3}$, Huang-Yao Hong ${ }^{4}$ \\ ${ }^{1}$ Western Sydney University, Australia \\ ${ }^{2}$ Nanyang Technological University, Singapore \\ ${ }^{3}$ Taiwan University of Science and Technology, Taiwan \\ ${ }^{4}$ National Chengchi University, Taiwan \\ Correspondence: Chwee Beng Lee, Western Sydney University, School of Education, Western Sydney University \\ Locked Bag 1797, Penrith NSW 2751, Australia, Tel: +61 2 47360719; Fax: +61 247360400.
}

\author{
Received: April 8, 2016 \\ doi:10.11114/jets.v4i8.1661 \\ Accepted: April 29, 2016 \\ Online Published: June 8, 2016 \\ URL: http://dx.doi.org/10.11114/jets.v4i8.1661
}

\begin{abstract}
In recent years, there have been many exchanges of perspectives and debates in the field of conceptual change. Most of the classical views on conceptual change have been criticized, and there have been recent discussions around bridging the cognitive and socio-cultural approaches in the research on conceptual change. On the other hand, researchers and educators in the knowledge building communities have been working towards advancing the frontier of knowledge work and knowledge creation in education in order to cope with the challenges of an emerging knowledge society. In this paper, we examine some of the main principles of knowledge building in relation to fostering conceptual change with reference to specific examples. Specifically, we highlight the foundational goal of knowledge building with respect to conceptual change.
\end{abstract}

Keywords: conceptual change, knowledge building, design mode

\section{Introduction}

For the past two decades, researchers and educators in the knowledge building communities have been working towards advancing the frontier of knowledge work and knowledge creation in education in order to cope with the challenges of an emerging knowledge society. As a learner-centred approach, knowledge building focuses on student-initiated problems of understanding the world and continual collaborative effort among students to improve their ideas; students assume collective cognitive responsibility in an environment of idea diversity and complexity to achieve new levels of knowledge and understanding (Scardamalia \& Bereiter, 2014, Scardamalia, 2002). Concurrently, in recent years, there have been many exchanges of perspectives and debates in the field of conceptual change (refer to Vosniadou, 2013; Vosniadou, 2011). Most of the classical views on conceptual change have been criticized, and there have been recent discussions around bridging the cognitive and socio-cultural approaches in the research on conceptual change.

In this paper, we examine some of the main principles of knowledge building in relation to fostering conceptual change with reference to specific examples. Specifically, we highlight the foundational goal of knowledge building with respect to conceptual change.

\section{Knowledge Building for Conceptual Change}

A knowledge building community can be illustrated by a committed scientist community where the members jointly identify authentic problems and assume collective responsibilities to advance their understanding and theories (Hewitt, 2001; Scardamalia, 2002). Unlike other communities of practice (Lave \& Wenger, 1999), the primary goal of a knowledge building community is to advance knowledge rather than to merely solve problems. This is similar to a "knowledge creating company" that focuses on idea improvement as the core activity of the whole organization (Bereiter \& Scardamalia, 2006). Scardamalia and Bereiter (2003) define knowledge building as "the production and continual improvement of ideas of value to a community, through means that increase the likelihood that what the community accomplishes will be greater than the sum of individual contributions and part of broader cultural efforts." (p. 1371). Knowledge building has been implemented in many K-12 classrooms (Hong \& Scardamalia, 2014; Lamon, Reeve, \& Scardamalia, 2001; Zhang, Hong, Scardamalia, Teo, \& Morley, 2011). 
Typically, in a classroom, the broad theme of inquiry relevant to a topic (e.g., environmental conservation) is first initiated by students, sometimes under the guidance of the teacher. The students then post their initial ideas and questions as notes in Knowledge Forum, an online asynchronous discussion forum created to augment knowledge building. The asynchronous online forum serves two key purposes: first, as a database to store students' ideas, and second, to make the students' ideas public. These reified ideas in public can then be discussed, explored, debated, and improved upon. Although most asynchronous online discussion forums can serve these purposes, a distinct feature of Knowledge Forum is their support of key features of knowledge building such as "rise-above" (Scardamalia \& Bereiter, 2006), that is, an intentional attempt to engage learners in a systematic way of relating ideas to one another in order to develop a higher-level understanding. The involvement of students throughout the inquiry helps to promote ownership and responsibility among the students and enhance the authenticity of the inquiry task (Scardamalia, Bereiter, Mclean, Swallow, Woodruff, 1989).

One of the explicit principles of knowledge building is idea improvement, which encourages the students to improve each other's ideas through various means such as reflecting, identifying relevant information, and conducting empirical experiments. Scaffolds are provided to engage the students in knowledge building discourse, which focuses on detecting gaps in understanding, sharing new knowledge, meaning-making, and co-constructing understanding. This is a social collaborative process which is typically conducted in both face-to-face and online sessions. It leads naturally to the growth and improvement of a database of ideas which reflects the progress of the community as a whole (Scardamalia \& Bereiter, 1994). As the initial questions are being addressed, the students are encouraged to ask further and deeper questions, thereby creating an ever-deepening pursuit of knowing. The students are also guided to organize and re-organize the ideas in the online forum. Knowledge building is thus an iterative process of progressive understanding, which Wells (1999) characterized as the "spiral of knowing" (p. 85).

Empirically, several studies have demonstrated the viability of knowledge building for conceptual change. Oshima and Scardamalia (1996) reported that students who engaged in knowledge building activities succeeded in attaining conceptual change. Chan, Burtis, Bereiter (1997) found knowledge building a mediator of cognitive conflict for conceptual change. Zhang, Scardamalia, Lamon, Messina, and Reeve (2007) studied a group of 4th graders who were actively involved in knowledge building activities such as generating theories and refining ideas to advance their understanding of optics. The students' understanding progressed from a naïve to a more scientific framework. Specifically, using post-hoc comparisons, they found a higher occurrence of scientific and hybrid ideas than pre-scientific ideas among the students. Similarly, when the Web Knowledge Forum (WebKF) was used to scaffold 6th graders in the process of constructing a model of the internal heating system of an average Greek house, the researchers found that the students showed significant improvement in their understanding of how a hot water heating system works (see Vosniadou \& Kollias, 2003). Empirical evidence of knowledge building for conceptual change is beginning to emerge. In addition, Lee (2010) also discusses the possibility of generating synergy between conceptual change and knowledge building.

In this paper, we argue that knowledge building may foster conceptual change for it can play the role of a mechanism for the development of learners' epistemic agency by situating them in the design mode of knowledge work (Bereiter \& Scardamalia, 2003).

\subsection{Knowledge Building for Progressive Improvement}

In conceptual change research, the notion of conceptual change is perceived and defined differently among the researchers (refer to Murphy \& Alexander, 2008), from weak restructuring to the more radical change across ontological categories (Carey, 1985; Chi, 1992; Vosniadou, 2008). Regardless, what is common is perhaps the implicit assumption of the ultimate standard for change - change from a naïve conception to the scientific conception held by scientific communities. Bereiter (1994) tackles this issue of standards using a different approach: rather than pursuing truth, focus on seeking progress. He disagrees with the "popular" postmodernist view that there is no objective truth; instead, he concurs with the postmodernist scholars that "there is no objective standpoint from which to judge whether something is an absolute truth" (p.4). Rather than getting into the debate on the postmodernist view about truth, his view suggests the standard of progressiveness. Concurring with the view of Popper and Lakatos that scientific theories cannot be verified, but can at most be falsified, he suggests progressive discourse as a means to bring in iterative critical evaluations of ideas, which could lead to the improvement or replacement of theories. In short, he proposes that through the dialectical process of presenting thesis and antithesis, new syntheses could arise.

Bereiter (1994) further elaborated on the moral commitment of progressive discourse for knowledge advancement: mutual understanding commitment (working towards common understanding), empirical testability commitment (a commitment to framing questions and propositions in a way which allows evidence to be brought to bear on them), expansion commitment (commitment to expand the body of collectively valid propositions), and openness commitment (commitment to allow any belief to be subjected to criticism if it will advance the discourse). This explicit goal of 
seeking progressive improvement is foundational to a number of key principles in knowledge building: idea improvement, constructive use of authoritative sources, volitional commitment to collective cognitive responsibility, rise above, epistemic agency, and knowledge building discourse (Scardamalia, 2002). More details of these principles will be given in our later discussion.

\section{Situating Learners in Design Mode for Conceptual Change}

We suggest that knowledge building can help learners develop the deep understanding that knowledge is tentative and evolving and that it consists of inter-related ideas. To accomplish this is to situate learners in a mode of design where the concern is with the creation and improvement of ideas as compared to belief mode where the concern is with evaluating and deciding among claims (Bereiter \& Scardamalia, 2006). The notion of engaging learners in design instead of belief mode demands a fundamental switch of ontological and epistemic stance towards how knowledge are being treated and is thus likely to lead to conceptual change. Further elaborations are provided below.

\subsection{Idea Improvement}

When situating learners in a design mode of knowledge work, the focus is on sustained idea development, it is the mode of invention and it is an explicit activity. Much attention is given to the construction, refinement and improvement of "conceptual artifacts", as Bereiter (2002) puts it, and to advancing understanding of the real world. According to Scardamalia (2002), ideas are "systematically interconnected - one idea subsumes, contradicts, constrains, or otherwise relates to a number of others" (p.72). This explication of idea is in alignment with the "complex theory-like structure" of concepts (Thagard, 1990; Vosniadou, 2007a, p.60) and the theory-based views of concepts that propose the organization of concepts as driven by personal theories of the world (Medin, 1989; Murphy \& Medin, 1999), based on casual and explanatory links as well as the attributes of individual concepts. In knowledge building, the learners engage in inquiry about a topic and create epistemic artifacts (Sterelny, 2005) like written notes to represent their conceptual understanding (Bereiter, 2002). The notion of epistemic artifacts is similar to Popper's (1972) construct of World 3 objects. Popper differentiated among World 1 objects (objects in the physical world), World 2 objects (objects in the subjective world within the individual's mind), and World 3 objects (cognitive artifacts, for example, theories created by scientists). To Popper, World 3 objects such as theories, once created, can generate a range of possibilities as others interact with them. They are treated as the currently best tentative explanations that should be subjected to error elimination in the search for truth.

Engaging learners in knowledge building is therefore getting them to articulate their ideas and also the relationships among the ideas, thus explicating both the concepts and the theory-like framework in which the concepts are situated. Sustained work in such environments is likely to foster an epistemic outlook that foregrounds ideas and theories as conceptual artifacts that can and should be examined and refined. For example, in a study by Hong, Chen, Chai, and Chan (2011), teacher-education students were guided to engage in knowledge building discourse about a topic concerning the "relationship between theory and practice in teaching." After a semester of knowledge building, it was found that the students were able to view the teaching theories they were working on as tentative and improvable, as one student commented in a Knowledge Forum note: "I am glad to see that we are gradually linking our ideas together. I believe we all think that 'a theory needs to be shaped again and again.' This is a process and also a procedure of strengthening a theoretical statement... I think theory itself is a conceptual sketch. No matter how it is challenged or shaped by the practice, the sketch will be modified and refined in a better way." (p. 476). Chai and Merry (2006) also reported that the knowledge building approach as a model of professional development changes the inservice teachers' views about teaching and learning.

In knowledge building, the learners' ideas are posted as online notes in a public space such as a Knowledge Forum database. They thus become shared objects of inquiry to be discussed, inter-connected, revised, and superseded by members of the community (Scardamalia, 2002; Stahl, 2006). In other words, all knowledge created is reified as "objects" that are open to further inquiry and improvement. In knowledge building, naïve ideas or alternative conceptions are not viewed as misconceptions. Rather, all ideas are considered as valuable and meaningful contributions, and initial ideas which may lack scientific explanations are regarded as a crucial starting point in the process of constructive idea improvement. Conceptual change researchers such as Vosniadou (2007a, 2007b) offer a similar view on concepts when she argues that what need to be changed are not the isolated misconceptions but the "naïve, intuitive, domain-specific theories in early childhood, on the basis of everyday experiences" (Vosniadou, 2007b, p. 4) and that children's intuitive ideas about science (or other subject matter) are anchoring conceptions that are the starting points for development (Clement, Brown, \& Zietsman, 1989; Karmiloff-Smith, 1992).

\subsection{Constructive Use of Authoritative Sources}

Another principle of knowledge building is the constructive use of authoritative sources (Scardamalia, 2002). Authoritative sources of knowledge refer to published knowledge constructed by experts available from media such as 
academic publications and textbooks; and in the case of school learning, the classroom teachers. What these sources articulate is often treated as the truth to be transmitted to learners, and hence is associated with traditional, didactic forms of teaching (Scardamalia \& Bereiter, 1999) that focus on the fidelity of the transmitted knowledge. As such, some researchers and educators are skeptical about the role of authoritative sources of knowledge in inquiry-based learning environments (e.g., Palinscar, 2006). Tsai (1999) and Tan (2008) reported that students have greater confidence in information presented in textbooks rather than in their own observations in laboratory works, which creates tensions when there is misalignment between practical observation and textbook representations. Their laboratory work is trying to confirm the facts presented in the textbooks (Tsai, 1999). Even when given a potato without buds, students tend to reproduce ideal representative diagrams seen in textbooks (a potato with buds) rather than what they observe in reality (Tan, 2008).

Knowledge building advocates meaningful use of authoritative sources of information to inform and produce iterative cycles of idea improvement (Zhang, Scardamalia, Lamon, Messina, \& Reeve, 2007). Rather than accepting the authoritative sources of information without question, learners must engage in meaning making of the information so that it can be used for enhancing their understanding of the topic under investigation. Similarly, Lee, Jonassen and Teo (2009) argued that for conceptual change to take place there must be significant efforts to restructure personal conceptual models. Such events take place when students challenge their own understanding and discover the inconsistencies in their conceptual structures while engaging in learning activities. They are then more likely to revise and refine their conceptual framework to resolve the cognitive conflict.

\subsection{Collective Cognitive Responsibilities}

In recent years, researchers from the conceptual change field have called for more consideration of both cognitive and sociocultural perspectives in the research of conceptual change, as they generally agree that both approaches are crucial in the process of conceptual change (Lee, 2010). In congruence with the emphasis on the sociocultural dimension of change, one of the explicit principles of knowledge building is collective cognitive responsibilities (Scardamalia, 2002). The principle legitimizes learners to offer diverse perspective to bear on the inquiry among a group of learners where idea improvement is achieved through the social interaction process. In knowledge building, much attention is given to organizing the social structures that could facilitate knowledge advancement (Hong, Scardamalia, \& Zhang, 2010; Scardamalia, Bereiter, \& Lamon, 1994). Knowledge building also draws from the notion of distributed cognition in a collaborative situation (Hong et al., 2015). It encourages learners to take on shared responsibilities of advancing the knowledge database, thus reducing the cognitive overload of individual learners while at the same time allowing the learners to develop differential expertise (Roth, 1999). The advantage is that learners with different backgrounds and abilities enter the learning environment with different ideas and perspectives. These diverse ideas and perspectives form the collective resources that learners can draw on. Such a learning environment creates multiple zones of proximal development where all learners can support each other mutually towards the achievement of the learning goals (Oshima, 1998). It also creates a natural social environment for the members to articulate and explain their ideas, which requires the members to be precise, concrete and coherent. In other words, the diversity of ideas naturally requires the learners to assess the viability of the ideas with multiple epistemic criteria (see earlier, Bereiter, 1994), leading to improvement in the ideas. Idea improvement, which could be for individual concepts or how the concepts are connected, is achieved through community effort. Ideas that are obvious misconceptions belong to the community and are treated collectively rather than as individual's misconceptions for the individual to resolve. The efficacy of the knowledge building approach that draws upon the community's distributed expertise and self-organizing capacity is illustrated by a recent study that spanned more than 15 years. Hong, Scardamalia, and Zhang (2010) explored different social interaction patterns in a community of knowledge building practitioners (with more than 350 participants). It was found that a knowledge group featured with more diverse expertise and more flexible and self-organizing social structures was more likely to create a dynamic network community for sustained and productive knowledge advancement.

\subsection{Rise Above}

In a nutshell, the knowledge building approach enriches learning by creating opportunities for members to understand from others' points of view and expose them to diverse ways of conceptualizing and investigating a given phenomenon (Guzdial et al., 1996). Related to this sociocultural perspective of conceptual change is another key knowledge building principle, rise above (Scardamalia, 2002), which requires the learners to work toward "more inclusive principles and higher-level formulations of problems. It means learning to work with diversity, complexity and messiness, and out of that achieve new syntheses." (p. 76). As a deliberate practice, rise above engages the learners in re-examining their ideas to achieve a new synthesis, which could mean seeking connections among ideas, or forming higher level theories from isolated facts. Such a learning environment where multiple ideas are shared and subjected to the scrutiny of every learner and the teacher provides fertile ground for seeing and organizing the relationships between various ideas such that the naturally formed theory-like framework is also worked on. The knowledge building environment thus fosters deep understanding and a process of conceptual change. 


\section{Epistemic Agency in Knowledge Building for Conceptual Change}

Epistemic agency refers to the development of more sophisticated epistemic beliefs required for learners to address all aspects of knowledge issues such as knowledge goals, self-assessment, motivation, systematic planning etc., as well as knowledge problems typically only addressed by teachers. In recent years, researchers involved in conceptual change research have mostly agreed that learners' epistemic beliefs play an important role in the course of conceptual change. For conceptual clarity, we use the term epistemic beliefs to refer to the nature of knowledge and ways of knowing, which is a notion commonly used in educational psychology (Hofer \& Pintrich, 1997). Vosniadou (2007b) emphasizes the direct or indirect influences of epistemic beliefs on conceptual change, and numerous studies (e.g., Mason, 2000; Sinatra, Southerland, McConaghy, \& Demastes, 2003) have also examined the relationships between epistemic beliefs and conceptual change. According to Murphy (2007), the relationship between belief and knowledge is complex and intertwined to the extent that they appear inseparable. In a knowledge building community, the participants work as epistemic agents in a design mode (Bereiter \& Scardamalia, 2006), i.e. they are engaged in interrogating ideas in terms of (1)What are they good for? (2) What do they do or fail to do? and (3) How can they be improved? The focus of the knowledge building effort is on the usefulness, adequacy, coherence, improvability, and development of ideas. The ways of knowing as practice in a knowledge building community naturally situate students in an epistemic environment where "all understandings are inventions" (Scardamalia \& Bereiter, 2006, p. 103). This will arguably translate into learners' active construction of their own knowledge, and alter students' epistemic agency, creating the potential for conceptual change (Lee, 2010). From the perspective of epistemic beliefs as the activation of epistemic resources for the task at hand (Louca, Elby, Hammer, \& Kagey, 2004), the knowledge building approach aims at launching students into the mode of knowledge creation (working on conceptual artifacts as World 3 objects) rather than learning (working on internal mental models and intuitive concepts). For example, in Hong, Chai, and Tsai's (2015) study that engaged college students to work as a knowledge building community and construct collective knowledge of history of science, it was found that students were able to progressively attain a more constructivist-oriented epistemic belief that sees scientific theories as tentative and improvable objects. Such a subtle difference in the epistemic framing of knowledge building and conceptual change needs careful attention to further unpack it.

In the recent development of the conceptual change research, the processes and mechanisms of change have been widely discussed, and there have been calls for more efficient mechanisms such as the use of analogies and explanatory models (Clement, 2008), mental models (Nersessian, 2008), persuasive pedagogy (Buehl, Manning, Cox, \& Fives, 2005; Edwards, Higley, Zeruth, \& Murphy, 2005), collaborative reasoning (Anderson et al., 2001; Clark, 2003; Mason, 2001), cognitive conflict (Tsai, 2000) and collaboration and reflection as social mechanisms (Miyake, 2008) to promote conceptual change. Entwistle (2007) suggests a deep approach to conceptual change which involves students paying careful attention to how well the evidence supports the conclusions. Such approaches are geared towards achieving intentional conceptual change which is a goal-oriented and learner controlled process (Sinatra \& Pintrich, 2003). In particular, Vosniadou (2007a, 2007b) cautioned that without intentional instruction-induced conceptual change, students might use additive mechanisms which could produce synthetic models of scientific understanding. Similarly, in knowledge building, there is an intentional change process for justifying knowledge claims: by engaging the learners in knowledge building discourse, rise above, and constructive use of authoritative sources of knowledge. What is more explicit in knowledge building is the effort devoted to developing learners' epistemic agency. An examination of the process and characteristics of knowledge building discourse is provided next.

\subsection{Knowledge Building Discourse}

One of the key principles of knowledge building is to engage students in knowledge building discourse (Bereiter, 1994, 2002), which develops in students the capacity to critique and improve ideas based on the negotiated criteria of a knowledge discipline. The learners start with their initial ideas and take responsibility for collaborative idea improvement supported by the customisable metacognitive prompts/scaffolds in the Knowledge Forum: "My theory is ...", "I need to understand ...", "This theory cannot explain ..." or "A better theory is...". Through knowledge building discourse, they learn to use evidence and logic to build their knowledge. These scaffolds encourage the students to think about their own ideas. Once their ideas are articulated and posted to the forum, they face the challenges of their peers' ideas and the ideas that the scientific community accepts. With the guidance of the teacher, their ideas are subjected to evaluation according to the criteria of the classroom community, which progressively emulates the science community. At an appropriate juncture, the teacher could organize knowledge building talks (e.g., see Zhang, Hong, Scardamalia, Teo, \& Morley, 2011) where students share their problems of understanding and knowledge advancement (e.g., findings from their investigation) with their peers in the class (Messina, Reeve, \& Scardamalia, 2003). These are explicit attempts to provide opportunities for the students to examine their ideas through self-evaluation and peer critiquing.

Knowledge building discourse has been described as "transformative discourse" (Hmelo-Silver \& Barrows, 2008, p. 51) 
as it serves more than the function of information sharing or the presentation of ideas; it entails the capacity to use appropriate criteria to assess ideas. For instance, as a way to examine students' online knowledge building discourse, Hong and Scardamalia (2014) used key terms to represent key concepts recorded in a knowledge database and to assess knowledge advancement in a grades 4 and 5 class community. They found that discourse in the Knowledge Forum which was rated as more reflective showed higher numbers and higher frequency use of key terms/concepts that were shared, discussed, referenced, or critiqued by community members than less reflective discourse. Using this kind of discourse, learners construct, refine, and transform knowledge (Hmelo-Silver \& Barrows, 2008). In short, knowledge building discourse encourages the students to engage in cognitive and metacognitive thinking; the individual's cognition is subjected to multiple perspectives and augmented by distributed intelligence in the classroom community. This could facilitate the restructuring of their naïve conceptual framework (Vosniadou \& Kollias, 2003), especially when students are creating rise above notes that synthesize the thesis and antithesis. Explanations generated as synthetic models will be under the scrutiny of peers and teachers and cannot be presented simply as facts to be remembered.

Imposing structural constraints and rise above are two strategies to acculturate students to engage in knowledge building discourse so as to justify their knowledge claims. One way the structural constraints are imposed is through the use of scaffolds that are reinforced with purposeful incorporation of technology such as a Knowledge Forum. As discussed earlier, the online forum affords a public space for sharing epistemic artifacts and for tracing the historical development of these artifacts. The online forum also helps to reinforce structural constraints like the customizable scaffolds to engage the students in metacognition. These cues are available to the students as they compose their notes. For example, some of the commonly used scaffolds include: "I need to understand...", and "This theory cannot explain..." Lee, Chan and van Aalst (2006) examined and described the role of knowledge building portfolios in students' collaborative inquiry. In their study, grade nine geography students identified clusters of computer notes that indicated knowledge building episodes in the computer discourse. The researchers suggested that when analyzing the online discourse, students can make the community's progress explicit and visible to themselves and others, thus leading to the reconstruction of individual students' own understanding. In addition, contributing to the knowledge building research, the researchers found that students who were working on portfolios with a set of guiding principles adapted and modified from the knowledge building principles illustrated by Scardamalia (2002) showed deeper inquiry and more conceptual understanding than their counterparts. The researchers suggested that providing knowledge building principles as scaffolds may help students understand progressive discourse.

The scaffoldings used in knowledge building are consistently used in the face-to-face and online environment. The online forum acts as cognitive tools (Perkins, 1993; Salomon, 1993) that assume the role of intellectual partners, relieving the learners of cognitively less critical tasks (like recording the discussion) and engaging them in thinking more critically. Cognitive tools are not "fingertip tools" (Perkins, 1993) that learners can use effortlessly; rather, they provide essential components of a learning environment that engage learners in thinking more critically than they would without that support. They encourage learners to exert greater cognitive effort in constructing their own knowledge (Salomon \& Globerson, 1987). Another intentional effort is the strategy of rise above. As explained earlier, rise above is a deliberate attempt to get learners to revisit their ideas which are often isolated or naïve. Learners are guided to re-examine their ideas for new syntheses, for connections among ideas, or for forming more inclusive principles, often with the use of scaffolds like "A better theory is ...", or "Putting our knowledge together..." In a Knowledge Forum, a rise above function is specifically developed to allow the learners to compose their rise above notes by subsuming several existing notes.

\section{Conclusion}

Conceptual change is an important goal of learning. Specifically in higher education, the achievement of this goal is highly dependent on effective college teaching, and the discussion of this paper about knowledge building pedagogy and principles should have implications for better engage students in fulfilling conceptual change as a learning goal. The empirical studies among preservice and inservice teachers reported above indicate that the knowledge building approach is likely to promote conceptual change. These findings however, need to be further studied in other higher education contexts. Nonetheless, the knowledge building approach is arguably fostering ontological and epistemic stance that is much needed for higher education reform given the $21^{\text {st }}$ century demands on innovation (Bereiter \& Scardamalia, 2006).

As the theoretical framework of conceptual change develops and reshapes over time, there is certainly the need to constantly look beyond our traditional pedagogical approaches and seek new ways to achieve conceptual change. In this paper, we discussed ideas from knowledge building that resonate well with the recent developments in conceptual change. Although we are still far from unravelling the full potential of knowledge building for conceptual change our effort could potentially inspire further cross pollination of productive ideas. This could also be a fertile ground for collaborative effort by researchers from the two fields. 


\section{References}

Anderson, R. C., Nguyen, J. K., McNurlen, B., Archodidou, A., Kim, S. Y., Reznitskaya, A., Tillmanns, M., \& Gilbert, L. (2001). The snowball phenomenon: Spread of ways of talking and ways of thinking across groups of children. Cognition and Instruction, 19(1), 1-46. http://dx.doi.org/10.1207/S1532690XCI1901_1

Bereiter, C. (1994). Implications of postmodernism for science, or science as progressive discourse. Educational Psychologist, 29, 3-12. http://dx.doi.org/10.1207/s15326985ep2901_1

Bereiter, C. (2002). Education and mind in the knowledge age. Mahwah, NJ: Lawrence Erlbaum.

Bereiter, C., \& Scardamalia, M. (2003). Learning to work creatively with knowledge. In E. de Corte, L. Vershaffel, N. Entwistle \& J. van Merrienboer (Eds.), Powerful learning environments: Unraveling basic componets and dimensions (55-68). Oxford, UK: Elsevier Science.

Berieter, C., \& Scardamalia, M. (2006). Education for the knowledge age: Design-centered models of teaching and instruction. In P. Alexander., \& P. Winne. (Eds.), Handbook of Educational Psychology (695-714). New York: Routledge.

Buehl, M. M., Manning, D. K., Cox, K., \& Fives, H. (2005, August). Exploring pre-service teachers' initial and informed reactions to persuasive pedagogy. In H. Fives (Chair), Teaching as persuasion: Is the metaphor viable? Symposium presented at the annual meeting of the American Psychological Association, Washington. DC.

Carey, S. (1985). Conceptual change in childhood. Cambridge, MA: MIT Press.

Chai, C. S., \& Merry, R. (2006). Teachers' Perceptions of Teaching and Learning in a Knowledge Building Community: An Exploratory Case Study. Learning, Media \& Technology, 31(2), 133-148. http://dx.doi.org/10.1080/17439880600756670

Chan, C. Burtis, J., \& Bereiter, C. (1997). Knowledge building as a mediator of conflict in conceptual change. Cognition and Instruction, 15(1), 1-40. http://dx.doi.org/10.1207/s1532690xci1501_1

Chi, M. T. H. (1992). Conceptual change within and across ontological categories: Examples from learning and discover in Science. In R. Giere (Ed.), Cognitive models of science: Minnesota Studies in the Philosophy of Science 129-186. Minneapolis: University of Minnesota Press.

Chin, C. A., \& Brewer, W. F. (1993). The role of anomalous data in knowledge acquisition: A theoretical framework and implications for science education. Review of Educational Research, 63, 1-49. http://dx.doi.org/10.3102/00346543063001001

Clement, J. (2008). The role of explanatory models in teaching for conceptual change. In S. Vosniadou (Ed), International handbook of research on conceptual change. 417-452. NY: Routledge.

Clement, J., Brown, D. E., \& Zietsman, A. (1989). Not all preconceptions are misconceptions: Finding 'anchoring conceptions' for grounding instruction on students' intuitions, International Journal of Science Education, 11, 554-565. http://dx.doi.org/10.1080/0950069890110507

Edwards, M. N., Higley, K., Zeruth, J. A., \& Murphy, P. K. (2005). The viability of the persuasion metaphor for educators with varying levels of teacher-efficacy. In H. Fives (Chair), Teaching as persuasion: Is the metaphor viable? Symposium presented at the annual meeting of the American Psychological Association, Washington, DC.

Entwistle, N. (2007). Conceptions of learning and the experience of understanding: Thresholds, contextual influences, and knowledge objects. In S. Vosniadou, \& A. Baltas, \& X. Vamvakoussi (Eds.), Reframing the conceptual change approach in learning and instruction. 123-144. Amsterdam: Elsevier.

Guzdial, M., Kolodner, J. L., Hmelo, C. E., Narrayanan, H., Carlson, D., Rappin, N., Hubscher, R., Turns, J., \& Newstetter, W. (1996). Computer support for learning through complex problem-solving. Communications of the ACM, 40, 39-42. http://dx.doi.org/10.1145/227210.227600

Hewitt, J. (2001). From a focus on tasks to a focus on understanding: The cultural transformation of a Toronto classroom. In Koschmann, T., Hall, R., \& Miyake, N. (Eds.), CSCL 2 carrying forward the conversation: Computers, cognition, and work 11-41. Mahwah, NJ: Lawrence Erlbaum Associates.

Hmelo, S. C. E., \& Barrows, H. S. (2008). Facilitating collaborative knowledge building. Cognition and Instruction, 26, 48-94. http://dx.doi.org/10.1080/07370000701798495

Hofer, B. K., \& Pintrich, P. R. (1997). The development of epistemological theories: Beliefs about knowledge and knowing and their relation to learning. Review of Educational Research, 67, 88-140. 
http://dx.doi.org/10.3102/00346543067001088

Hong, H. Y., \& Scardamalia, M. (2014). Community knowledge assessment in a knowledge building environment. Computers \& Education, 71, 279-288. http://dx.doi.org/10.1016/j.compedu.2013.09.009

Hong, H. Y., Chai, C. S., \& Tsai, C. C. (2015). College Students Constructing Collective Knowledge of Natural Science History in a Collaborative Knowledge Building Community. Journal of Science Education and Technology, 24(5), 549-561. http://dx.doi.org/10.1007/s10956-015-9546-8

Hong, H. Y., Chen, F. C., Chai, C. S., \& Chan, W. C. (2011). Teacher-education students' views about knowledge building theory and practice. Instructional Science, 39(4), 467-482. http://dx.doi.org/10.1007/s11251-010-9143-4

Hong, H. Y., Scardamalia, M., \& Zhang, J. (2010). Knowledge Society Network: Toward a dynamic, sustained network for building knowledge. Canadian Journal of Learning and Technology/La revue canadienne de l'apprentissage et de la technologie, 36(1).

Hong, H. Y., Scardamalia, M., Messina, R., \& Teo, C. (2008, June). Principle-based design to foster adaptive use of technology for building community knowledge. In Proceedings of the 8th international conference on International conference for the learning sciences-Volume 1 (pp. 374-381). International Society of the Learning Sciences.

Jonassen, D. H. (2008). Model building for conceptual change. In S. Vosniadou (Ed), International handbook of research on conceptual change. (pp.676-693). NY: Routledge.

Karmiloff, S. A. (1992) Beyond Modularity: a developmental perspective on cognitive science. Cambridge, MA: MIT Press.

Lamon, M., Reeve, R. \& Scardamalia, M. (2001, April). Mapping the growth of deeply principled understandings in a knowledge building community. Annual Meeting of the American Educational Research Association. Seattle, WA. Retrieved 2 September 2009 from http://ikit.org/lamon/mapping.html

Lave, J., \& Wenger, E. (1999). Legitimate peripheral participation in the communities of practice. In R. McCormick, \& C. Paechter (Eds.). Learning and knowledge 21-35. Thousand Oaks, CA: SAGE Publication.

Lee, C. B. (2010). Generating synergy between knowledge building and conceptual change, Human Development, 53(3), 134-152. http://dx.doi.org/10.1159/000315170

Lee, C. B., Jonassen, D. H., \& Teo, T. (2009). The Role of Model Building in Problem Solving and Conceptual Change. Journal of Interactive Learning Environments, 19(3), 247-265. http://dx.doi.org/10.1080/10494820902850158

Mason, L. (2000). Role of anomalous data and epistemological beliefs in middle school students' theory change about two controversial topics. European Journal of Psychology of Education, 15 (3), 329-246. http://dx.doi.org/10.1007/BF03173183

Medin, D. L. (1989). Concepts and conceptual structure. American Psychologist, 44(12), 1469-1481. http://dx.doi.org/10.1037/0003-066X.44.12.1469

Messina, R., Reeve, R., \& Scardamalia, M. (2003). Collaborative structures supporting knowledge building: Grade 4. A paper presented at the Annual Meeting of the American Educational Research Association, April 22, 2003, Chicago, Illinois.

Miyake, N. (2008). Conceptual change through collaboration. In S. Vosniadou (Ed), International handbook of research on conceptual change. 453-478. NY: Routledge.

Murphy, P. K. (2007). The eye of the beholder: The interplay of social and cognitive components in change. Educational Psychologist, 42(1), 41-53. http://dx.doi.org/10.1080/00461520709336917

Murphy, P. K., \& Alexander, P. A. (2008). The role of knowledge, beliefs, and interest in the conceptual change process: A synthesis and meta-analysis of the research. In S. Vosniadou (Ed), International handbook of research on conceptual change. 583-618. NY: Routledge.

Murphy, P. K., Alexander, P. A., Greene, J. A., \& Edwards, M. N. (2007). Epistemological threads in the fabric of conceptual change research. In S. Vosniadou, \& A. Baltas, \& X. Vamvakoussi (Eds.), Reframing the conceptual change approach in learning and instruction. 105-122. Amsterdam: Elsevier.

Murphy. G., \& Medin, D. L. (1999). The role of conceptual coherence. In E. Margolis \& S. Laurence (Eds.), Concepts: Core readings 425-458. Cambridge: MIT Press.

Nersessian, N. J. (2008). Mental modelling in conceptual change. In S. Vosniadou (Ed), International handbook of research on conceptual change. 391-416. NY: Routledge. 
Oshima, J. (1998) Differences in knowledge-building between two types of networked learning environments: An information analysis. Journal of Educational Computing Research, 19(3), 329-351. http://dx.doi.org/10.2190/YLLX-M9CW-15X9-BJJ9

Oshima, J., \& Scardamalia, M. (1996). Knowledge-building and conceptual change: an inquiry into student-directed construction of scientific explanations. Proceedings of the 1996 international conference on Learning sciences, 256-263.

Palinscar, A. S. (2006). Reading in science: Why, what and how. Retrieved 2 September 2009 from http://www.umich.edu/ govrel/adoles_lit/Palincsar.pdf

Perkins, D. N. (1993). Person-plus: A distributed view of thinking and learning. In G. Salomon, (Ed.), Distributed cognitions: Psychological and educational considerations 88-110. Cambridge, UK: Cambridge University Press.

Popper, K. R. 1972. Objective Knowledge: An Evolutionary Approach. Oxford: Clarendon Press.

Roth, W. (1999). Authentic school science. In R. McCormick, \& C. Paechter (Eds.). Learning and knowledge 6-20. Thousand Oaks, CA: SAGE Publication.

Salomon, G. (1993). On the nature of pedagogic computer tools: The case of the writing partner. In S.P. Lajoie \& S.J. Derry (Eds.). Computers as cognitive tools. (pp. 179-196). Hillsdale, NJ: Lawrence Erlbaum Associates.

Salomon, G., \& Globerson, T. (1987). Skill may not be enough: The role of mindfulness in learning and transfer. International Journal of Educational Research, 11, 623-638. http://dx.doi.org/10.1016/0883-0355(87)90006-1

Scardamalia, M. (2002). Collective cognitive responsibility for the advancement of knowledge. In B. Smith (Ed.), Liberal education in a knowledge society. 67-98. Chicago: Open Court.

Scardamalia, M., \& Bereiter, C. (1994). Computer support for knowledge-building communities. The Journal of the Learning Sciences, 3(3), 265-283. http://dx.doi.org/10.1207/s15327809j1s0303_3

Scardamalia, M., \& Bereiter, C. (1999) Schools as knowledge-building organizations. In D. Keating \& C. Hertzman (Eds.), Today's children, tomorrow's society: The developmental health and wealth of nations 274-289. New York: Guilford.

Scardamalia, M., \& Bereiter, C. (2003). Knowledge Building. In Encyclopaedia of Education. (2nd ed., pp.1370-1373). New York: Macmillan Reference, USA.

Scardamalia, M., \& Bereiter, C. (2006). Knowledge building: Theory, pedagogy, and technology. In Sawyer, R. K. (Eds.). The Cambridge handbook of the learning sciences (pp. 97-118). Cambridge University Press. http://dx.doi.org/10.1017/cbo9781139519526.025

Scardamalia, M., \& Bereiter, C. (2014). Knowledge building and knowledge creation: Theory, pedagogy, and technology. In Sawyer, R. K. (Eds.). The Cambridge handbook of the learning sciences (2 ${ }^{\text {nd }}$ ed.) 397-417. Cambridge University Press.

Scardamalia, M., Bereiter, C., \& Lamon, M. (1994). The CSILE project: Trying to bring the classroom into world 3. In K. McGilly (Ed.), Classroom lessons: Integrating cognitive theory and classroom practice (pp.201-228). Cambridge, MA: Bradford Books/MIT Press.

Scardamalia, M., Bereiter, C., McLean, R., Swallow, J., \& Woodruff, E. (1989). Computer supported intentional learning er4nvironments, Journal of Educational Computing Research 5(1), 51-68.

Sinatra, G. M., \& Mason, L. (2008). Beyond knowledge: Learner characteristics influencing conceptual change. In S. Vosniadou (Ed), International handbook of research on conceptual change. (pp.560-582). NY: Routledge

Sinatra, G. M., \& Pintrich, P. R. (2003). The role of intentions in conceptual learning. In Sinatra, G. M., \& Pintrich, P. R. (Eds.), Intentional conceptual change 1-18. Mahwah, NJ: Lawrence Erlbaum Associates.

Sinatra, G. M., Brem, S. K., \& Evans, E. M. (2008). Changing minds? Implications of conceptual change for teaching and learning about biological evolution. Evolution: Education and Outreach, 1(2), 189-195. http://dx.doi.org/10.1007/s12052-008-0037-8

Sinatra, G. M., Southerland, S. A., McConaughy, F., \& Demastes, J. (2003). Intentions and beliefs in students' understanding and acceptance of biology evolution. Journal of Research in Science Teaching, 40(5), 510-528. http://dx.doi.org/10.1002/tea.10087

Sterelny, K. (2005). Externalism, epistemic artefacts and the extended mind. In R. Schantz (Ed.). The externalist challenge: New studies on cognition and intentionality. Berlin: de Gruyter. 
Tan, G. (2008). Group cognition: Computer support for building collaborative knowledge. Cambridge, MA: The MIT Press.

Thagard, P. (1990). Concepts and conceptual change. Synthese, 82, 255-274. http://dx.doi.org/10.1007/BF00413664

Tsai, C. C. (1999). 'Laboratory exercises help me memorize the scientific truths': A study of Eight graders' scientific epistemological views and learning in laboratory activities. Science Education, 83, 654-674. http://dx.doi.org/10.1002/(SICI)1098-237X(199911)83:6<654::AID-SCE2>3.0.CO;2-Y

Tsai, C. C. (2000). Enhancing science instruction: The use of "conflict maps." International Journal of Science Education, 22, 285-302. http://dx.doi.org/10.1080/095006900289886

Vosniadou, S. (2007a). The cognitive-situative divide and the problem of conceptual change, Educational Psychologist, 42(1), 55-66. http://dx.doi.org/10.1080/00461520709336918

Vosniadou, S. (2007b). The conceptual change approach and its re-framing. In Vosniadou, S., Baltas, A., \& Vamvakoussi, X. (Eds). Reframing the conceptual change approach in learning and instruction 1-16. Amsterdam: Elsevier.

Vosniadou, S. (2008). International handbook of research on conceptual change NY: Routledge.

Vosniadou, S., \& Brewer, W. F. (1994). Mental models of the day/night cycle. Cognitive Science, 18,123-183. http://dx.doi.org/10.1207/s15516709 $\operatorname{cog} 1801 \_4$

Vosniadou, S., \& Kollias, V. (2003). Using collaborative, computer-supported, model building to promote conceptual change in Science. In De Corte, E., Verschaffel, L., Entwistle, N., \& Van Merrienboer, J. (Eds.). Powerful learning environments: Unravelling basic components and dimensions 181-196. Amsterdam: Earli.

Wells, G. (1999). Dialogic inquiry: Toward a sociocultural practice and theory of education. New York, NY: Cambridge University Press. http://dx.doi.org/10.1017/CBO9780511605895

Zhang, J., Hong, H. Y., Scardamalia, M., Teo, C. L., \& Morley, E. A. (2011). Sustaining knowledge building as a principle-based innovation at an elementary school. The Journal of the Learning Sciences, 20(2), 262-307.Zhang, J., Scardamalia, M., Lamon, M., Messina, R., \& Reeve, R. (2007). Socio-cognitive dynamics of knowledge building in the work of 9- and 10-years-olds. Education Technology, Research and Development, 55, 117-145. http://dx.doi.org/10.1080/10508406.2011.528317

\section{(cc) BY}

This work is licensed under a Creative Commons Attribution 3.0 License. 